\title{
Effects of napropamide on microbiological characteristics of tobacco rhizosphere soil and its dissipation
}

\author{
X.M. Wu ${ }^{1,2 *}$ Y.H. Long ${ }^{1,2}$, Y.R. Li ${ }^{1}$, R.X. $\operatorname{Liu}^{2}, \mathrm{M}^{2} \mathrm{Li}^{1}$ \\ ${ }^{1}$ Department of Plant Protection, Agriculture College, Guizhou University, Huaxi District Guiyang 550025, People’s Republic \\ of China. ${ }^{2}$ Guizhou Key Laboratory for Tobacco Quality, Huaxi District Guiyang 550025, People's Republic of China. \\ *Corresponding author: im21959@163.com
}

\begin{abstract}
Knowledge of microbiological characteristics in the plant rhizosphere is essential for understanding the fate and transport of agricultural chemicals in soils. The present study was conducted to investigate the effects of an acetanilide herbicide napropamide on microbiological characteristics of tobacco (Nicotiana tabacum K326) rhizosphere soil and its dissipation behaviors under controlled conditions. The results showed that both microbial populations and enzymatic activities in rhizosphere soil were higher than those in non-rhizosphere soil. The populations of bacteria and actinomycetes decreased with napropamide addition in rhizosphere soil, while the populations of fungi displayed the decreasing, recovering and increasing trend throughout the incubation period. The activities of dehydrogenase and catalase were stimulated firstly, owing to napropamide addition, then were inhibited, and recovered to the control level, whereas the activities of urease were inhibited obviously during the testing stage. Napropamide rapidly dissipated in vegetated soil suggests that rhizosphere soil is a useful pathway to rapidly remove or detoxify herbicide residues.
\end{abstract}

Keywords: Napropamide, rhizosphere, microorganism, enzyme, dissipation

\section{Introduction}

Extensive use of pesticides, while being of great benefit in controlling pathogens, insects, and weeds in agricultural systems, can also threaten environmental quality. For example, when pesticides are applied to soils, they may interact with non-target soil microorganisms, have a chronic adverse effect on soil health, and result in bioaccumulation in ecosystems and thus contamination of crops (Burrows and Edwards, 2002; Seeger et al., 2010). Owing to their xenobiotic characteristics, some pesticides, especially those persistent in soils, constitute a very important group of contaminants. A1though these pesticides have been restrictively used or even banned for several years, their existence and bioaccumulation can still be found in soil and plants (Galanopoulou et al., 2005; Gevao et al., 2000). As a result, the residues of these pesticides in soils have caused enhancing concern. There is a need, thus, for the sustainable development 
of agriculture, to have new soil management practices related with the fate and transport of agricultural chemicals to meet the challenge of conservation, remediation, and environmental quality.

The plant rhizosphere is the narrow region of soil that is directly influenced by root secretions and associated soil microorganisms. The microbial numbers, microbial activity and soil enzymatic activity in the rhizosphere are typically an order of magnitude higher than in the non-rhizosphere (Hartmann et al., 2009). These phenomena often result in accelerating dissipation of organic chemicals in the root zone compared with the non-rhizosphere region (He et al., 2006; Plangklang and Reungsang, 2008; Singh et al., 2004; Sun et al., 2004; Yang et al., 2011). The variety of plants and chemicals for which this has been observed and the remediation processes associated with the rhizosphere were recently reviewed. In general, the results of these studies have shown that plant rooting systems appear to be most effective in enhancing dissipation rates of organic compounds compared to non-rhizosphere soil (Anderson et al., 1994; Chaudhry et al., 2005; He et al., 2006; Korade and Fulekar, 2009; Plangklang and Reungsang, 2008; Yang et al., 2011).

Napropamide [N, N-diethyl-2-(1-naphthalenyloxy) propanamide] is an acetanilide herbicide widely used for pre-emergence control of annual grasses and some broad-leaved weeds in a wide range of crop field since its introduction to China. The effects of napropamide on soil quantity and its fate and transport have aroused increasing concern due to its relatively high water solubility, relatively long persistence in soils, and significant toxicological properties (Biswas et al., 2007; Barrett and Ashton, 1981; Cui and Yang, 2011; Guo et al., 2008, 2009; Walker et al., 1985; Zhang et al., 2010). The effects of napropamide on soil microbial properties and its residual behaviors in soils after application have been previously investigated. Napropamide residues have been shown to potentially influence on soil microbial biomass and enzymatic activities (Guo et al., 2009; Cycoń et al., 2013 a, b). The dissipation half-life of napropamide in soils varies from 25 to $152 \mathrm{~d}$, depending on soil types and properties (Biswas et al., 2007; Guo et al., 2008; Walker et al., 1985). To date, however, little information is available about the effects of this herbicide on microbiological characteristics of rhizosphere soil and its persistence in the plant rhizosphere soils.

The objectives of the present study were to evaluate the effects of napropamide on microbial populations and enzymatic activities of tobacco rhizosphere soil and to determine the dissipation behavior of napropamide in rhizosphere soil. This information will be useful for understanding the potential adverse effects of napropamide on soil quantity and for predicting the environmental fate of this herbicide in tobacco field soil environment.

\section{Materials and Methods}

\subsection{Herbicide, culture medium and soil}

Technical grade napropamide ( $99.5 \%$ purity) was purchased from Dima Technology Inc., USA. The commercial formulation of napropamide $(50 \%$ water dispersible granule (WDG), Jiangsu Kuaida Agrochemical Co., Ltd, Jiangsu, China) was used for soil treatment. The chemical reagents used in the experiments were analytical grade or HPLC grade.

Nutrient agar medium ( $\mathrm{pH} 7$ ) containing (in $\mathrm{g} \mathrm{L}^{-1}$ ): 3.0, beef extract; 10.0, peptone; 18.0, agar. Czapek's agar medium (natural $\mathrm{pH}$ ) consisting (in $\mathrm{g} \mathrm{L}^{-1}$ ):2.0, $\mathrm{NaNO}_{3}$; $1.0, \mathrm{~K}_{2} \mathrm{HPO}_{4} ; 0.5, \mathrm{MgSO}_{4} 7 \mathrm{H}_{2} \mathrm{O} ; 0.01, \mathrm{FeSO}_{4} 7 \mathrm{H}_{2} \mathrm{O}$; 30.0, sucrose; $0.5, \mathrm{KCl} ; 18.0$, agar. The modified starch nitrate agar medium ( $\mathrm{pH} 7$ ) consisting (in $\mathrm{g} \mathrm{L}^{-1}$ ): 0.5 , $\mathrm{NaCl} ; 1.0, \mathrm{KNO}_{3} ; 0.5, \mathrm{~K}_{2} \mathrm{HPO}_{4} ; 0.5, \mathrm{MgSO}_{4} \cdot 7 \mathrm{H}_{2} \mathrm{O}$; 0.01, $\mathrm{FeSO}_{4} \mathrm{H}_{2} \mathrm{O} ; 20.0$, soluble starch; 18.0, agar.

Rhizosphere soil was collected, together with tobacco plants (N. tabacum K326) at the stubble stage in tobacco fields of Huaxi District, Guiyang City, Guizhou Province, China. Rhizospheres were excavated by digging around and close to the plant 
roots with the depth to approximately $15 \mathrm{~cm}$ below ground. The extra soil around the root zone was shaken out and the rhizosphere soil which was soil attached to the root was then collected and passed through a $2 \mathrm{~mm}$ sieve. Non-rhizosphere soil was taken from the same site and then passed through $2 \mathrm{~mm}$ sieve. All soils were placed in plastic bags and kept at $4{ }^{\circ} \mathrm{C}$ before usage in the experiment. The soil was classified as silt loam, and its properties were as follows: organic matter content, $3.94 \%$; clay, $22.31 \%$; sand, $34.38 \%$; silt, 43.31\%; cationic exchange capacity, $22.31 \mathrm{cmol}$ $\mathrm{kg}^{-1}$; and $\mathrm{pH} 6.32$.

\subsection{Soil treatment and sampling}

Rhizosphere and non-rhizosphere soil samples $(2.0 \mathrm{~kg}$ dry weight equivalent) were spiked with napropamide WDG coupled with an appropriate volume of sterile distilled water at an initial concentration of $6.0 \mathrm{mg}$ $\mathrm{kg}^{-1}$ on dry weight basis. Soil samples were mixed thoroughly using a plastic spoon and passed through a 2-mm sieve to distribute the herbicide evenly. Soil samples were left for $1 \mathrm{~h}$ on a laminar flow bench to allow the solvent to evaporate, and then transferred to a 3-L polypropylene pot. The pot was then covered with aluminum foil. Control soil samples were treated similarly with sterile distilled water without napropamide. Soil moisture content was adjusted to $60 \%$ of water-holding capacity and maintained constantly by periodic addition with sterile distilled water as necessary. Soil samples were incubated in darkness at $25 \pm 1{ }^{\circ} \mathrm{C}$ for $60 \mathrm{~d}$. At intervals of 1, 3, 7, $14,21,30,45$, and $60 \mathrm{~d}$ after herbicide application, $30.0 \mathrm{~g}$ of soil samples were removed from each treatment using a $2-\mathrm{cm}$ diameter soil auger to conduct microbiological and enzyme assays. In addition, $10.0 \mathrm{~g}$ of soil samples were removed at $0,7,14,30$, and $60 \mathrm{~d}$, to analyze napropamide residues using HPLC.

\subsection{Measurement of soil microbial populations}

Microbial populations were isolated by serial dilution on media and enumerated by the most-probablenumber (MPN) technique described elsewhere
(NISCAS, 1985). Briefly, total bacteria, total fungi, and total actinomycetes were determined on nutrient agar medium, Czapek's agar medium, and the modified starch nitrate agar medium, respectively. The inoculated agar plates were incubated at $30 \pm 1$ ${ }^{\circ} \mathrm{C}$ for $2 \mathrm{~d}$ for bacteria and fungi and $13 \mathrm{~d}$ for actinomycetes prior to the colonies were counted.

\subsection{Measurement of soil enzymatic activities}

Activities of dehydrogenase, catalase and urease were assayed according to methodology outlined by Guan et al. (1986). Briefly, to determine dehydrogenase activity, $5.0 \mathrm{~g}$ soil was reacted with triphenyltetrazolium chloride (TTC) at $30{ }^{\circ} \mathrm{C}$ for $24 \mathrm{~h}$, and triphenyl-formazane (TPF) of a reductive product of TTC was determined spectrophoto-metrically at $492 \mathrm{~nm}$. For measurement of catalase activity, $2.0 \mathrm{~g}$ soil was reacted with $\mathrm{H}_{2} \mathrm{O}_{2}$ at $25{ }^{\circ} \mathrm{C}$ for 20 min, and the residual $\mathrm{H}_{2} \mathrm{O}_{2}$ was determined by titration with $\mathrm{KMnO}_{4}$ in the presence of $\mathrm{H}_{2} \mathrm{SO}_{4}$. For determination of urease activity, an aliquot of soil $(5.0 \mathrm{~g})$ was reacted with urea at $37{ }^{\circ} \mathrm{C}$ for $24 \mathrm{~h}$, and the released ammonium was determined spectrophoto-metrically at $578 \mathrm{~nm}$.

\subsection{Analysis of napropamide residues in soil}

The soil samples were mixed with $30 \mathrm{~mL}$ acetonewater $(25: 5, \mathrm{v} / \mathrm{v})$, extracted for $2 \mathrm{~h}$ on a reciprocating shaker and for 20 min under ultrasonic bath at 20 ${ }^{\circ} \mathrm{C}$, respectively. After filtration, acetone within the filtrate was allowed to evaporate. Solution of 2 $\mathrm{mL}$ was taken and passed through a $0.45 \mu \mathrm{m}$ nylon membrane syringe filter prior to analysis by Wasters $600 \mathrm{E}$ HPLC equipped with a $\mathrm{C}_{18}$ column $(150 \times 4.6$ $\mathrm{mm}$ i.d., $5 \mu \mathrm{m}$ ) and a UV detector operating at 220 $\mathrm{nm}$. The mobile phase was acetonitrile-water $(80: 20$, $\mathrm{v} / \mathrm{v})$. The column temperature was kept at $30{ }^{\circ} \mathrm{C}$ and flow rate was $1 \mathrm{~mL} / \mathrm{min}^{-1}$. The retention time was $6.6 \mathrm{~min}$. The limit of detection was $0.012 \mathrm{mg} \mathrm{kg}^{-1}$. Average recoveries from soils fortified at levels of 0.05-5.0 $\mathrm{mg} \mathrm{kg}^{-1}$ ranged from 85.1 to $96.2 \%$ with relative standard deviations of $2.3-4.6 \%$. 


\subsection{Data analysis}

All analyses were performed in four replicates. All the values reported were expressed as per g oven-dried soil $\left(105^{\circ} \mathrm{C}\right)$. Data were analyzed statistically by analysis of variance (ANOVA). Least Significant Difference (LSD) test was employed to assess differences between the treatment means. The effects of napropamide on soil microbial population and enzyme activity data were declared as significant at $5 \%$ probability levels. The difference between dissipation hail-lives of napropamide in rhizosphere and non-rhizosphere soils were assessed using Pearson correlation coefficient test. All statistical analyses were performed with SPSS12.0 software.

\section{Results and Discussion}

\subsection{Effects of napropamide on soil microbial populations}

The effects of napropamide application on the culturable populations of bacteria, fungi, and actinomycetes are shown in Figure $1 \mathrm{a}, \mathrm{b}$, and c, respectively. The populations of bacteria, fungi, and actinomycetes in rhizosphere soil were significantly higher than those in non-rhizosphere soil during the whole incubation period, indicating that the rhizosphere effect is evident. Due to the addition of napropamide, total counts of bacteria and actinomycetes in both rhizosphere and non-rhizosphere soils were significantly lower than the control after incubation for two and three weeks, respectively. These inhibitory effects seemed to be transient. The populations of bacteria and actinomycetes were recovered to the level that was similar to that of the control after incubation of 21 and $30 \mathrm{~d}$, respectively. Like bacteria, the populations of fungi in rhizosphere and non-rhizosphere soils were inhibited in the initial stage for about two weeks and recovered to the level of the control at $21 \mathrm{~d}$ of inhibition. Following that time, however, the numbers of fungi group in rhizosphere soil were significantly higher than that in rhizosphere control within the later one month, and a similar phenomenon was observed in non-rhizosphere soil. It seems to be likely that fungi were more resistant to napropamide than bacteria and actinomycetes, although the populations of fungi were less than those of bacteria and actinomycetes. It is possible that fungi might turn into the dominant microbial type degrading napropamide after the application of napropamide in soil.

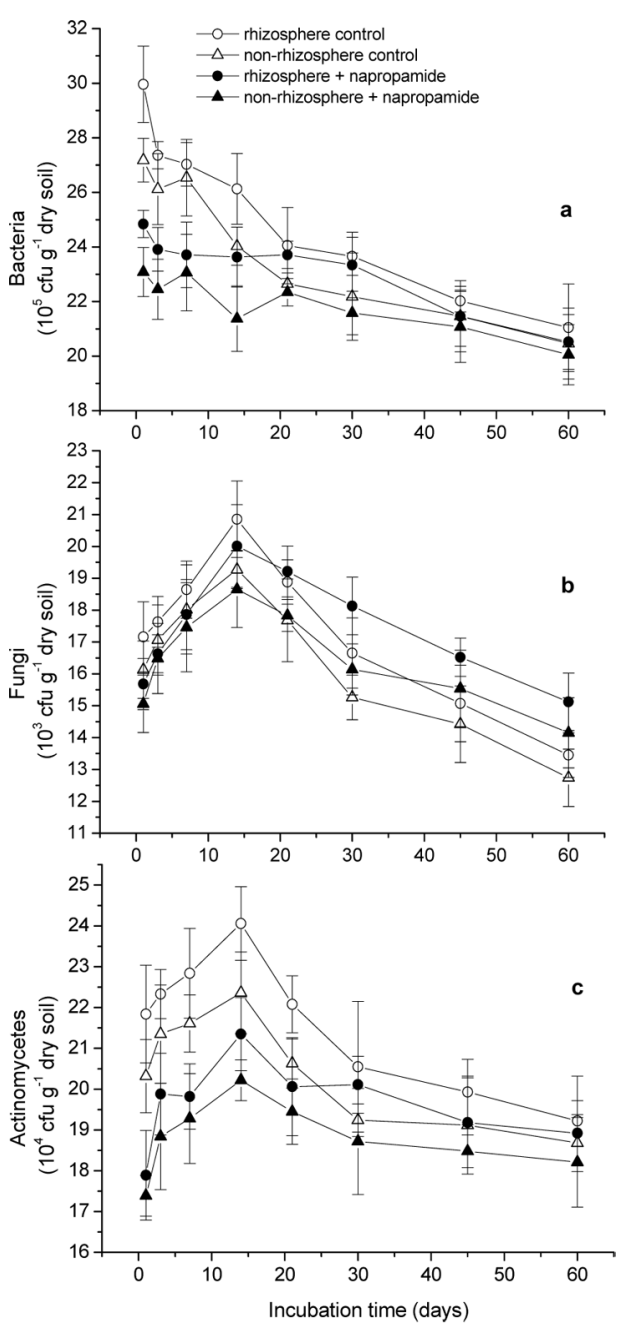

Figure 1. Effects of napropamide application on populations of bacteria (a), fungi (b) and actinomycetes (c) in rhizosphere and non-rhizosphere soils 
The following dissipation data revealed that the half life of napropamide in rhizosphere soil and nonrhizosphere soil was 47.5 and $55.9 \mathrm{~d}$, respectively, and this herbicide seemed to be utilized as an energy source by soil microorganisms. It can also be conclude from the Figure 1 that the planting of tobacco is beneficial to the growth and reproduction of microorganism population, regardless of whether or not napropamide was applied. For example, the numbers of bacteria, fungi and actinomycetes in rhizosphere soil were 1.0 to 1.3 fold more than in non-rhizosphere soil during testing period. The proliferation of microorganisms in soil appears to be stimulated by the planting of tobacco crops, and then the dissipation or detoxification of microorganisms on napropamide is evidently enhanced. This provides the theoretical basis for the in-site bioremediation of acetanilide herbicide-polluted soil by the combination of plants and microorganisms (Chaudhry et al., 2005; Hartmann et al., 2009; Korade and Fulekar, 2009; Yu et al., 2003).

\subsection{Effects of napropamide on soil enzymatic activities}

Soil enzymes, key indicators of soil health, are the catalysts of importantly biochemical processes including the decomposition of organic pollutants and the detoxification of xenobiotics (Chaudhry et al., 2005; Rao et al., 2010; Hartmann et al., 2009). The levels of activities of dehydrogenase, catalase, and urease in rhizosphere and non-rhizosphere soils in response to the napropamide addition are shown in Figure 2 a, b, and c, respectively. Like microorganisms, the effects of napropamide on soil enzyme activities were depended on enzyme types and incubation time. Within the initial 3 and $14 \mathrm{~d}$ of incubation, activities of dehydrogenase and catalase in rhizosphere and non-rhizosphere soils treated with napropamide showed significant increase compared with the control, respectively. However, napropamide application displayed the obvious inhibitory effects on activities of dehydrogenase and catalase after 7 and 21 $\mathrm{d}$ of incubation, respectively. At the end of incubation, activities of both dehydrogenase and catalase recovered to the level of the control. In contrast, throughout the incubation period, the urease activities in rhizosphere and non-rhizosphere soils treated with napropamide was lower than that in the control. It was found that, by comparison, activities of dehydrogenase, catalase, and urease were 1.0 to 1.2 fold higher in rhizosphere soil than non-rhizosphere soil (Figure 2).
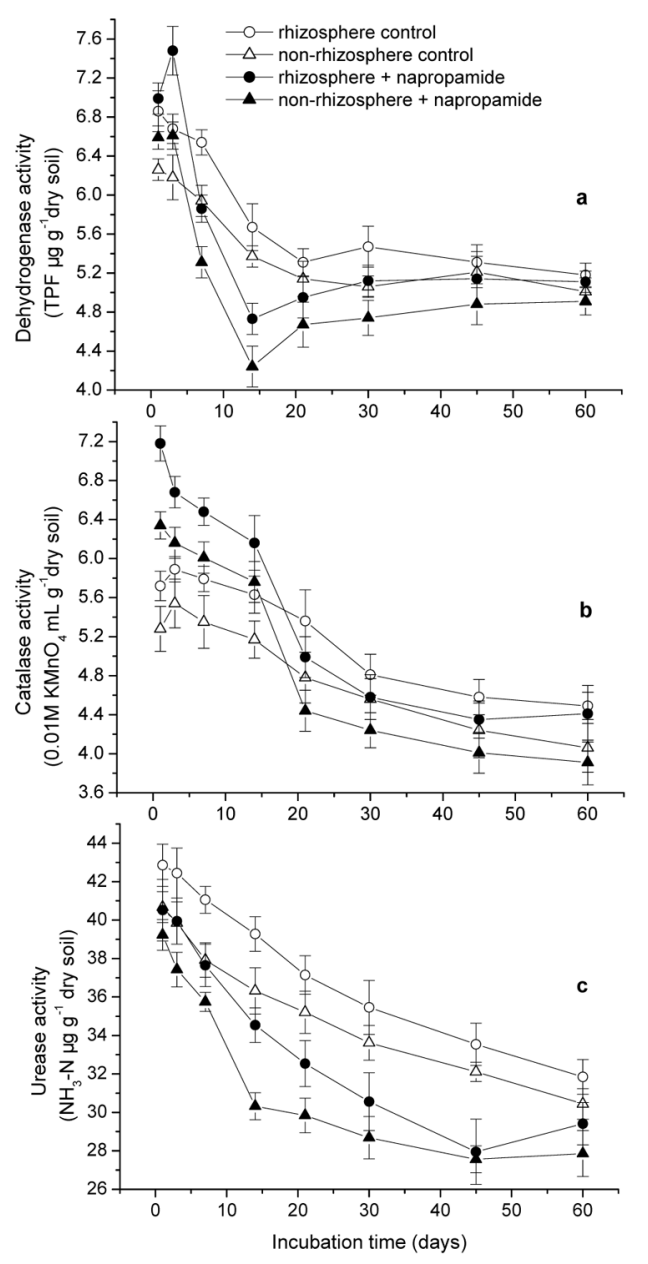

Figure 2. Effects of napropamide on activities of dehydrogenase (a), catalase (b), and urease (c) in rhizosphere and non-rhizosphere soils 
Soil enzyme activity measured in these assays represents enzyme association with the living organisms in soil. Increased levels of the enzyme activity observed in rhizosphere soil agree with elevated microbial populations, suggesting the potential for enhanced dissipation of herbicide napropamide. These results are in agreement with those obtained in previous studies in the cases of other herbicides such as diuron (Romero et al., 2010), metsulfuron-methyl (He et al., 2006), and metolachlor (Staddon et al., 2001).

\subsection{Dissipation of napropamide in rhizosphere soil}

The dissipation dynamics of napropamide in rhizosphere soil and non-rhizosphere soil were shown in Figure 3. The dissipation of napropamide in soil was described by a first-order reaction kinetic model and showed good performance for rhizosphere soil and non-rhizosphere soil, with $r^{2}$ values of 0.9498 and 0.9409 , respectively. The residual levels of napropamide in rhizosphere soil were significantly lower than those in non-rhizosphere soil over the entire period of observations except at the beginning. At the end of incubation $(60 \mathrm{~d})$, for example, the residual concentrations of napropamide in rhizosphere soil decreased by $15.8 \%$ compared to those in non-rhizosphere soil.

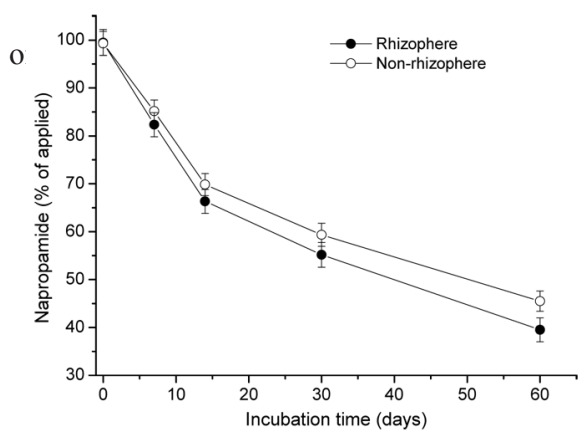

Figure 3. Dissipation dynamics of napropamide in rhizosphere and non-rhizosphere soils
Results presented here indicated that napropamide rapidly dissipated in rhizosphere soil with half-lives of $47.5 \mathrm{~d}$, which were approximately 1.2 fold faster than in non-rhizosphere soil (55.9 d). There was significant difference in half-lives between rhizosphere soil and non-rhizosphere soil (Paired t test, $p<0.05$ ). This might be resulted from numbers of microorganisms degrading napropamide in rhizosphere soils were greater than in non-rhizosphere soil (Figure 1) resulting in the rapid dissipation of napropamide in rhizosphere soil.

Similar findings were reported previously in other studies by Plangklang and Reungsang (2008), Singh et al. (2004), Sun et al. (2004), and Yu et al. (2003) in which the dissipation rates of pesticides were improved in rhizosphere soil of different plants. Dissipation of aldicarb and oxime, carbamate insecticides, in rhizosphere soil of corn, mung bean and cowpea, was found to be more rapid than in unplanted soil (Sun et al., 2004). Two times shorter half-life of butachlor was observed in rhizosphere soil compared with nonvegetated soil indicating the enhancement of butachlor dissipation by wheat rhizosphere soil (Yu et al., 2003). Anderson et al. (1994) demonstrated that rhizosphere soil had an order of magnitude higher microbial numbers in Kochia sp. rhizosphere soil compared with unplanted soil leading to a significantly enhanced dissipation of atrazine, metolachlor and trifluralin mixed in soil. The incidents of more rapid dissipation of pesticides in planted soils than in unplanted soil might be due to the fact that rhizosphere soil contains important sources of nutrients supporting the growth and reproduction of microorganisms capable of degrading various types of chemicals in soil (Hartmann et al., 2009; Korade and Fulekar, 2009). This leaded to a larger number of microorganisms and more rapid dissipation of pesticides in rhizosphere soil than in non-rhizosphere soil (Anderson et al., 1994; Chaudhry et al., 2005; He et al., 2006; Plangklang and Reungsang, 2008; Sun et al., 2004; Singh et al., 2004; Yang et al., 2011). 
Successful hizosphere remediationand bioaugmentation of pesticides and organic hydrocarbons by the planting of plants was found in previous studies. For instance, a shorter $T_{1 / 2}$ of butachlor in inoculated wheat rhizosphere soil than in non-inoculated rhizosphere soil and in non-rhizosphere soil was reported by $\mathrm{Yu}$ et al. (2003). The inoculation of atrazine degrading bacteria to the soil could accelerate mineralization of atrazine in soil (Topp, 2001). Three-fold increase in mineralization of atrazine was also observed in soil inoculated with Chelatobater heintzii Cit1 (Rousseaux et al., 2003). The strain B-14 inoculated to soil treated with chlorpyrifos at $35 \mathrm{mg} \mathrm{kg}^{-1}$ enhanced dissipation of chlorpyrifos in soil (Singh et al., 2004). Korade and Fulekar (2009) revealed that the percentage dissipation of chlorpyrifos was $100 \%$ in rhizosphere soil inoculated with ryegrass (Lolium multiflorum, var. PRG-1) as compared to 76.24 , 90.36 and $90.80 \%$ in non-inoculated soil for initial concentrations of 25,50 and $100 \mathrm{mg} \mathrm{kg}^{-1}$ at 14,21 and $28 \mathrm{~d}$ of incubation, respectively.

\section{Conclusions}

An understanding of microbiological characteristics in the rhizosphere of herbicide-tolerant plants is fundamental for biologically remediating pesticidecontaminated sites. Results presented here indicated that both microbial populations and enzymatic activities in rhizosphere soil were higher than those in non-rhizosphere soil. The effects of napropamide on rhizosphere soil microbial populations and enzyme activities were depended on microorganism and enzyme types and incubation time. The fungi might be the dominant microbial type degrading napropamide. The rapid dissipation of napropamide in vegetated soil suggests that rhizosphere soil is a useful pathway to rapidly remove or detoxify herbicide residues.

\section{Acknowledgments}

This work was supported by the National Natural Science Foundation of China (No.21267007, 31000204), the National High Technology R\&D Program of China (No. 2012AA06A204), the Agricultural Research Projects of Science and Technology Department of Guizhou Province (No. [2012]3010), the Science and Technique Foundation of Guizhou Province (No. [2010]2074), and the Senior Talent Introduction Research Program of Guizhou University (No. (2011)06).

\section{References}

Anderson, J.A., Kruger, E.L., Coats, J.R. 1994. Enhanced degradation of a mixture of three herbicides in the rhizosphere of a herbicidetolerant plant. Chemosphere. 28(8), 1551-1557.

Barrett, M., Ashton, F.M. 1981. Napropamide uptake, transport, and metabolism in corn (Zea mays) and tomato (Lycopersicon esculentum). Weed Sci. 29(6), 697-703.

Biswas, P.K., Pramanik, S.K., Mitra, S.R., Bhattacharyya, A. 2007. Persistence of napropamide in/on tea under north-east Indian climatic condition. Bull. Environ. Contam. Toxicol. 79(5), 566-569.

Burrows, L.A., Edwards, C.A. 2002. The use of integrated soil microcosms to predict effects of pesticides on soil ecosystems. Ecotoxicology.13, 143-161.

Chaudhry, Q., Blom-Zandstra, M., Gupta, S., Joner, E.J. 2005. Utilising the synergy between plants and rhizosphere microorganisms to enhance breakdown of organic pollutants in the environment. Environ. Sci. Pollut. Res. 12 (1), 34-48. 
Cui L.E., Yang H. 2011. Accumulation and residue of napropamide in alfalfa (Medicago sativa) and soil involved in toxic response. J. Hazard Mater. 190, 81-86.

Cycoń M., Markowicz A., Piotrowska-Seget Z. 2013a. Structural and functional diversity of bacterial community in soil treated with the herbicide napropamide estimated by the DGGE, CLPP and $\mathrm{r} / \mathrm{K}$-strategy approaches. Appl.Soil Ecol. 72, 242-250.

Cycoń, M., Wójcik, M., Borymski, S., PiotrowskaSeget, Z. 2013b. Short-term effects of the herbicide napropamide on the activity and structure of the soil microbial community assessed by the multiapproach analysis. Appl.Soil Ecol. 66, 8-18.

Galanopoulou, S., Vgenopoulos, A., Conispoliatis, N. 2005. DDTs and other chlorinated organic pesticides and polychlorinated biphenyls pollution in the surface sediments of Keratsini harbour, Saronikos gulf, Greece. Mar. Pollut. Bull. 50, 520-525.

Gevao. B., Semple, K.T., Jones, K.C. 2000. Bound pesticide residues in soils: a review. Environ. Pollut. 108(1), 3-14.

Guan, S.Y., Zhang, D.S., Zhang, Z.M. 1986. Soil enzymes and its methodology, Agricultural Press, Beijing.

Guo, H., Chen, G., Lv, Z., Zhao, H., Yang, H. 2009. Alteration of microbial properties and community structure in soils exposed to napropamide. J. Environ. Sci. 21(4), 494-502.

Guo, H., Zhu, H.M., Yang, H. 2008. Degradation and adsorption behavior of napropamide in soils. Environ. Sci. 29(6), 729-1736.

Hartmann, A., Schmid, M., van Tuinen, D., Berg, G., 2009. Plant-driven selection of microbes. Plant Soil. 321, 235-257.
He, Y.H., Shen, D.S., Fang, C.R., He.R., Zhu,Y.M 2006. Effects of metsulfuron-methyl on the microbial population and enzyme activities in wheat rhizosphere soil. J. Environ. Sci. Health B. 41(3), 269-284.

Korade, D.L., Fulekar, M.H. 2009. Rhizosphere remediation of chlorpyrifos in mycorrhizospheric soil using ryegrass. J. Hazard. Mater. 172, 1344-1350.

Nanjing Institute of Soil, Chinese Academy of Science (NISCAS). 1985. Soil microorganism research methods, Science Press, Beijing.

Plangklang, P., Reungsang, A. 2008. Effects of rhizosphere remediation and bioaugmentation on carbofuran removal from soil. World J. Microbiol. Biotechnol. 24(7), 983-989.

Rao, M.A., Scelza, R., Scotti, R., Gianfreda, L. 2010. Role of enzyme in the remediation of polluted environments. J. soil sci. plant nutr. 10(3), 333353.

Romero, E., Fernández-Bayo, J., Díaz, J.M.C., Nogales, R. 2010. Enzyme activities and diuron persistence in soil amended with vermicompost derived from spent grape marc and treated with urea. Appl. Soil Ecol. 44(3), 198-204.

Rousseaux, S., Hartmann, A., Lagacherie, B., Piutti, S., Andreux, F., Soulas, G. 2003. Inoculation of an atrazine-degrading strain, Chelatobacter heintzii Cit1, in four different soils: effects of different inoculums densities. Chemosphere. 51(7), 569-576.

Seeger, M., Hernández, M., Méndez, V., Ponce, B., Córdova, M., González, M. 2010. Bacterial degradation and bioremediation of chlorinated herbicides and biphenyls. J. Soil Sci. Plant Nutr. 10 (3), 320-332.

Singh, N., Megharaj, M., Kookana, R.S., Naidu, R., Sethunathan, N. 2004. Atrazine and simazine 
degradation in pennisetum rhizosphere. Chemosphere. 56(3), 257-263.

Staddon, W.J., Locke, M.A., Zablotowicz, R.M. 2001. Microbiological characteristics of a vegetative buffer strip soil and degradation and sorption of metolachlor. Soil Sci. Soc. Am. J. 65(4), 1136-1142.

Sun, H., Xu, J., Yang, S., Liu, G., Dai, S. 2004. Plant uptake of aldicarb from contaminated soil and its enhanced degradation in the rhizosphere. Chemosphere. 54(4), 569-574.

Topp, E. 2001. A comparison of three atrazinedegrading bacteria for soil bioremediation. Biol. Fertil. Soils. 33(6), 529-534.
Walker, A., Brown, P.A., Mathews, P.R. 1985. Persistence and phytotoxicity of napropamide residues in soil. Ann.Appl.Bio. 106(2), 323-333.

Yang, C., Wang, Y., Li, J. 2011. Plant species mediate rhizosphere microbial activity and biodegradation dynamics in a riparian soil treated with bensulfuron-methyl. Clean-Soil, Air Water. 39 (4), 338-344.

Yu, Y.L., Chen, Y.X., Luo, Y.M., Pan, X.D., He, Y.F., Wong, M.H. 2003. Rapid degradation of butachlor in wheat rhizosphere soil. Chemosphere. 50(6), 771-774.

Zhang, R., Cui, J., Zhu, H.M., Yang, H. 2010. Effect of dissolved organic matters on napropamide availability and ecotoxicity in Rapeseed (Brassica napus). J. Agric. Food Chem. 58(5), 3232-3240. 